\title{
Improving access to care by allowing self-referral to a hepatitis C clinic
}

\author{
Karen Doucette MD MSc FRCPC 1 , Vicki Robson RN², Stephen Shafran MD ${ }^{1}$, Dennis Kunimoto MD ${ }^{1}$
}

K Doucette, V Robson, S Shafran, D Kunimoto. Improving access to care by allowing self-referral to a hepatitis $\mathrm{C}$ clinic. Can J Gastroenterol 2009;23(6):421-424.

BACKGROUND: Estimates suggest that more than 250,000 Canadians are infected with hepatitis $\mathrm{C}$ virus (HCV), but less than $10 \%$ have been treated. Access to specialists in Canada is usually via health care professional (HCP) referral and, therefore, may be a barrier to $\mathrm{HCV}$ care. However, clinics that operate in conjunction with the Hepatitis Support Program, Edmonton, Alberta, allow self-referral. It is hypothesized that this improves access to care without increasing inappropriate referrals.

OBJECTIVE: To compare the baseline characteristcs and outcomes of HCV patients who self-referred with those who were HCP-referred.

METHODS: Data were collected from the Hepatitis Support Program HCV database and chart reviews.

RESULTS: Between December 17, 2002, and December 31, 2007, 1563 patients were referred including 336 self- (21.5\%) and $1227 \mathrm{HCP}$ referrals (78.5\%). Self- and HCP-referred patients were similar in terms of age (mean $[ \pm \mathrm{SD}] 43.0 \pm 10.3$ years versus $43.9 \pm 10.0$ years, respectively; $\mathrm{P}=0.18)$, sex $(56.8 \%$ versus $62.0 \%$ [men], respectively; $\mathrm{P}=0.08$ ) and risk factors for $\mathrm{HCV}(\mathrm{P}=0.3)$, with $49.7 \%$ and $52.6 \%$, respectively, identifying injection drug use as the primary risk factor. The two groups had similar HCV genotype distributions and liver biopsy fibrosis scores with similar treatment rates $(31.3 \%$ versus $33.2 \%$; $\mathrm{P}=0.6)$. Treatment outcomes were excellent (sustained virological response $40.2 \%$ for genotype 1, 67\% for genotypes 2 and 3 ) in patients completing therapy and were similar between the two groups.

CONCLUSION: Self-referred patients comprised $21.5 \%$ of patients accessing care in the clinic. Self- and HCP-referred patients had similar characteristics, treatment rates and outcomes. Facilitating selfreferral to an HCV clinic can improve access to care, including risk reduction education and $\mathrm{HCV}$ treatment.

Key Words: Antiviral therapy; Health services accessibility, Hepatitis C

$T_{\mathrm{h}}^{\mathrm{h}}$ he prevalence of hepatitis $\mathrm{C}$ virus $(\mathrm{HCV})$ infection in Canada is estimated to be $0.8 \%$ to $1 \%$ (ie, more than 250,000 Canadians) (1). It is estimated that approximately 5000 individuals are newly infected each year. Because this exceeds the annual estimated HCV-related mortality and cure rate of therapy, the prevalence is predicted to rise. Modelling suggests that by 2022, the number of hepatitis C-related deaths and the number of liver transplants needed because of HCV will increase by one-third (2). Despite these startling predictions of future disease burden and the availability of effective HCV therapy, it is estimated that only $65 \%$ of HCV-infected Canadians have been identified and of those, less than $10 \%$ (approximately 12,000 to 15,000) have been treated for HCV (2). To limit the impact of chronic HCV infection on the

\section{Améliorer l'accès aux soins en autorisant l'auto-aiguillage vers une clinique d'hépatite $\mathrm{C}$}

HISTORIQUE : Selon les estimations, plus de 250000 Canadiens sont infectés par le virus de l'hépatite C (VHC), mais moins de $10 \%$ sont traités. En général, pour accéder à un spécialiste au Canada, il faut obtenir l'aiguillage d'un professionnel de la santé (PDS), ce qui peut constituer un obstacle aux soins du VHC. Cependant, les cliniques qui fonctionnent conjointement avec le programme de soutien de l'hépatite d'Edmonton, en Alberta, autorisent les auto-aiguillages. On postule que cette autorisation améliore l'accès aux soins sans accroître les aiguillages inopportuns.

OBJECTIF : Comparer les caractéristiques de départ et les issues des patients qui se sont auto-aiguillés à celles des patients aiguillés par un PDS.

MÉTHODOLOGIE : Les données ont été colligées dans la base de données du VHC et les dossiers du programme de soutien de l'hépatite.

RÉSULTATS : Du 17 décembre 2002 au 31 décembre 2007, 1563 patients ont été aiguillés, y compris 336 auto-aiguillages (21,5\%) et 1227 aiguillages par un PDS (78,5\%). Les patients auto-aiguillés et aiguillés par un PDS étaient similaires pour ce qui est de l'âge (âge moyen [ \pm ÉT] de 43,0 $\pm 10,3$ ans par rapport à 43,9 $\pm 10,0$ ans, respectivement; $\mathrm{P}=0,18)$, du sexe ( $56,8 \%$ par rapport à $62,0 \%$ [hommes], respectivement; $\mathrm{P}=0,08)$ et des facteurs de risque du $\mathrm{VHC}(\mathrm{P}=0,3)$, tandis que $49,7 \%$ et $52,6 \%$, respectivement, déclaraient les drogues par injection comme facteur de risque primaire. Les deux groupes avaient une répartition génotypique du VHC similaire et des indices de fibrose à la biopsie du foie aux taux de traitement similaires $(31,3 \%$ par rapport à 33,2 \%; $\mathrm{P}=0,6)$. Les issues des traitements étaient excellentes (réponse virologique soutenue de 40,2\% pour le génotype 1 et de $67 \%$ pour les génotypes 2 et 3) chez les patients qui terminaient la thérapie et étaient similaires dans les deux groupes.

CONCLUSIONS : Les patients auto-aiguillés représentaient 21,5 \% des patients qui accédaient aux soins à la clinique. Les patients auto-aiguillés et aiguillés par un PDS avaient des caractéristiques, des taux de traitement et des issues similaires. Le fait de faciliter les auto-aiguillages vers une clinique du VHC peut améliorer l'accès aux soins, y compris l'éducation sur la réduction des risques et le traitement du VHC.

Canadian health care system, efforts need to be made to ensure that all patients with $\mathrm{HCV}$ infection are identified and have access to care, including appropriate HCV therapy and risk reduction education.

Approximately $20 \%$ of $\mathrm{HCV}$ infections in Canada are among the immigrant population, and the majority of new $\mathrm{HCV}$ infections acquired in Canada are related to injection drug use (2). Access to health care in both of these populations may be less than optimal; consequently, they require physician referral, which is considered to represent a barrier to accessing $\mathrm{HCV}$ care. In many jurisdictions, self-referral is inherently discouraged by fee-for-service remuneration of physicians, which typically pays significantly less for nonreferred compared with referred consultations. An alternate remuneration plan

${ }^{1}$ Division of Infectious Diseases, University of Alberta; ${ }^{2}$ Hepatitis Support Program, Alberta Health Services, Edmonton, Alberta

Correspondence: Dr Karen Doucette, Division of Infectious Diseases, University of Alberta, WMC 2E4.20, 8440 - 112 Street, Edmonton,

Alberta T6G 2B7. Telephone 780-407-1620, fax 780-407-7137, e-mail karen.doucette@ualberta.ca

Received for publication October 27, 2008. Accepted December 25, 2008 


\begin{tabular}{|c|c|c|}
\hline Characteristic & $\begin{array}{l}\text { Self-referred } \\
(n=336)\end{array}$ & $\begin{array}{c}\begin{array}{c}\text { HCP-referred } \\
(n=1227)\end{array} \\
\end{array}$ \\
\hline Age, years (mean \pm SD) & $43.0 \pm 10.3$ & $43.9 \pm 10.0$ \\
\hline Male sex & $191(56.8)$ & $761(62.0)$ \\
\hline \multicolumn{3}{|l|}{ Hepatitis C virus risk factor* } \\
\hline Injection drug use & $167(49.7)$ & $646(52.6)$ \\
\hline Transfusion & $23(6.8)$ & $112(9.1)$ \\
\hline Tattoo & $15(4.5)$ & $68(5.5)$ \\
\hline Immigrant/therapeutic injection & $16(4.8)$ & $52(4.2)$ \\
\hline None stated & $93(27.7)$ & $292(23.8)$ \\
\hline Other & $22(6.5)$ & $57(4.6)$ \\
\hline No bloodwork & $63(18.8)$ & $177(14.4)$ \\
\hline Hepatitis C virus RNA negative & $45(16.5)$ & $168(16)$ \\
\hline \multicolumn{3}{|l|}{ Liver biopsy } \\
\hline Not performed ${ }^{\dagger}$ & $245(72.9)$ & $848(69.1)$ \\
\hline Clinical cirrhosis & $3(0.9)$ & $6(0.5)$ \\
\hline Hepatitis C virus genotype $^{\ddagger}$ & $(n=225)$ & $(n=877)$ \\
\hline 1 & $170(75.6)$ & $594(67.7)$ \\
\hline 2 & $19(8.4)$ & $84(9.6)$ \\
\hline 3 & $35(15.6)$ & $190(21.7)$ \\
\hline 4,5 or 6 & $1(0.4)$ & $9(1)$ \\
\hline Fibrosis stage on biopsy§ & $(n=88)$ & $(n=373)$ \\
\hline Fo & $21(23.9)$ & $53(14.2)$ \\
\hline F1 & $43(48.9)$ & $170(45.6)$ \\
\hline F2 & $17(19.3)$ & $82(22)$ \\
\hline F3 & $4(4.5)$ & $51(13.7)$ \\
\hline F4 & $3(3.4)$ & $17(4.5)$ \\
\hline
\end{tabular}

Data are presented as $n$ (\%) unless specified otherwise. *Risk factor as recorded in nursing assessment; ${ }^{\dagger}$ No biopsy and no clinical evidence of cirrhosis; ¥Unable to genotype in eight subjects; ${ }^{\S}$ Biopsies assessed by METAVIR score

that does not rely on a fee-for-service model facilitates the physicians in the Division of Infectious Diseases of the University of Alberta and the Hepatitis Support Program (administered by Alberta Health Services), Edmonton, Alberta, in accepting referrals not only from physicians but also from other health care providers (eg, nurse clinicians, public health professionals) as well as self-referrals. Information and education are provided initially by a nurse who also completes a baseline assessment that includes history, risk factors, physical examination, a standard laboratory panel and abdominal ultrasonography. Once the results of investigations are complete, the patient is seen by a physician for further discussion of management and therapy.

The objectives of the present study were to determine the proportion of patients referred to the Hepatitis Support Program by a health care professional (HCP) (physician or other) and patient self-referral, and to compare the baseline characteristics and outcomes of patients referred by HCPs with those who were self-referred.

\section{METHODS}

Data were extracted from the Hepatitis Support Program database and from chart reviews. All patients referred from December 17, 2002, to December 31, 2007, were included in the analysis with follow-up completed to June 30, 2008. Data collected included the source of referral (self or physician/other HCP), demographics (age, sex), risk factors for HCV infection, qualitative serum HCV RNA, HCV genotype, whether $\mathrm{HCV}$ treatment was started and outcome of treatment.

The baseline characteristics and outcomes of treatment were compared between the two groups (self- versus HCPreferred) using $\chi^{2}$, Fisher's exact and $t$ tests, as appropriate. Data were analyzed using SAS v9.1 (SAS Institute Inc, USA) statistical software. The study was approved by the University of Alberta Health Research Ethics Board.

\section{RESULTS}

Between December 17, 2002, and December 31, 2007, a total of 1563 patients were referred to the Hepatitis Support Program (Division of Infectious Diseases). This included 336 individuals who were self-referred (21.5\%) and 1227 who were referred by physicians or other HCPs (78.5\%). Patients who self-referred were not routinely asked why they contacted the program directly rather than obtaining an HCP referral. However, when recorded, the most commonly stated reasons included lack of a family physician; told by a family physician to call directly; and told by a family physician that there was no treatment for $\mathrm{HCV}$ or that their infection was 'dormant' but the patient wanted additional information.

The baseline characteristics of subjects who self-referred were similar to those who were HCP-referred and are summarized in Table 1 . There were no statistically significant differences between the two groups in terms of age, sex or risk factors for HCV infection. Injection drug use was identified as the primary risk factor in $49.7 \%$ of self- and $52.6 \%$ of HCP-referred patients ( $\mathrm{P}$ not significant). Similarly, the proportion of patients who were immigrants from a more highly HCVendemic country was comparable in the two groups and was the only identifiable risk factor for $\mathrm{HCV}$ in $4.8 \%$ of self- and $4.2 \%$ of HCP-referred patients (P not significant). The proportion who were HCV RNA negative, the proportion who failed to have baseline laboratory results and the distribution of $\mathrm{HCV}$ genotypes were also similar between the two groups. A similar proportion of patients in the self- and HCP-referred groups attended the initial nursing assessment $(77.4 \%$ versus $78.8 \%$, respectively; $\mathrm{P}=0.6)$. A total of 950 patients (193 [57.4\%] selfand 757 [61.7\%] HCP-referred; $\mathrm{P}=0.2$ ) attended the initial physician appointment.

Among the 950 patients who were assessed by a physician, a total of $326(34.3 \%)$ were treated for HCV, including 66 in the self- and 260 in the HCP-referred group $(\mathrm{P}=0.5)$. The proportion undergoing liver biopsy and the METAVIR fibrosis scores (3) were similar in the two groups. Common reasons documented for not treating the patient included mild disease on liver biopsy, active drug or alcohol abuse, patient declined or deferred therapy, and medical comorbidities. Of the 326 patients who commenced therapy, 43 patients $(13.2 \%)$ were treated in a research protocol and were therefore excluded from further outcome analysis. The proportion of subjects entering research studies was similar in the two groups.

The characteristics and outcomes of the 283 patients treated with standard therapy (pegylated interferon alfa-2a or pegylated interferon alfa-2b combined with ribavirin [4-6]) are summarized in Table 2. With follow-up completed to June 30, 
TABLE 2

Characteristics and outcomes of patients treated for hepatitis $\mathrm{C}$ virus with pegylated interferon and ribavirin $(n=283)$

\begin{tabular}{lcc}
\hline Characteristic & $\begin{array}{c}\text { Health care } \\
\text { professional- } \\
\text { referred } \\
\text { (n=224) }\end{array}$ \\
\hline Hepatitis C virus genotype & $35(59.3)$ & $124(55.4)$ \\
1 & $8(13.6)$ & $30(13.4)$ \\
2 & $16(27.1)$ & $67(29.9)$ \\
3 & 0 & $3(1.3)$ \\
4 & $26(44.1)$ & $93(41.5)$ \\
Outcome of therapy & $9(15.2)$ & $41(18.3)$ \\
Sustained virological response (SVR) & $2(3.4)$ & $20(8.9)$ \\
Nonresponder & $1(1.7)$ & $10(4.5)$ \\
Relapse & 0 & $5(2.2)$ \\
End of treatment response, SVR pending & $8(13.6)$ & $28(12.5)$ \\
Breakthrough & $10(16.9)$ & $23(10.3)$ \\
Early stop; AE & $3(5.1)$ & $4(1.8)$ \\
On treatment & $\begin{array}{c}\text { (n) } \\
\text { Lost to follow-up }\end{array}$ & \\
\hline
\end{tabular}

Data are presented as $n$ (\%). AE adverse effect of antiviral therapy

2008, similar proportions in the two groups were documented to have achieved a sustained virological response (SVR). Of the patients started on therapy in the study period, 33 were still on treatment at the end of follow-up, 11 had achieved an end of treatment response and were awaiting assessment of SVR, and seven patients were lost to follow-up.

A total of 232 patients completed therapy as well as $\mathrm{HCV}$ RNA testing to document the final virological response (45 selfand $187 \mathrm{HCP}$-referred). The outcome of therapy in these patients is summarized in Table 3. Overall, an SVR was achieved in 119 patients $(51.3 \%)$ and was similar in the two groups ( $57.8 \%$ versus $49.7 \%$, respectively; P not significant). When compared by HCV genotype, the proportion acheiving an SVR was also similar in the two groups, with 53 of 132 (40.2\%) genotype 1 and 65 of 97 (67\%) genotype 2 or 3 patients achieving an SVR.

\section{DISCUSSION}

Allowing self-referral to specialists has been shown to increase access to relevant expert care in HIV-infected individuals in the United States (7). Our data demonstrate that self-referral also increases access to specialist hepatitis $\mathrm{C}$ care in Canada. During the five-year study period, $21.5 \%$ of our patients were self-referred. In the United States, the inability to self-refer may be a barrier to specialist care because it is linked to the patient's insurance coverage, whereas in Canada self-referral is hindered by physician remuneration policies that commonly pay more for referred consultations. In our setting, self-referral is facilitated by an alternate remuneration plan that does not rely on a fee-for-service model. Eliminating the financial disincentive to physicians for accepting self-referral in other parts of Canada may improve access to hepatitis $\mathrm{C}$ care.

Although the reason for self-referral was not routinely documented, the primary reason recorded was the lack of access to a primary health care provider to initiate the referral. The
TABLE 3

Virological response in hepatitis $\mathbf{C}$ patients who completed pegylated interferon and ribavirin therapy, and follow-up $(n=232)$

\begin{tabular}{lcc}
\hline Characteristic & $\begin{array}{c}\text { Self-referred } \\
(\mathbf{n}=\mathbf{4 5})\end{array}$ & $\begin{array}{c}\text { Health care } \\
\text { professional- } \\
\text { referred }(\mathbf{n = 1 8 7})\end{array}$ \\
\hline $\begin{array}{l}\text { Virological response } \\
\text { Sustained virological response }\end{array}$ & $26(57.8)$ & $93(49.7)$ \\
Nonresponder & $9(20)$ & $41(21.9)$ \\
Relapse & $2(4.4)$ & $20(10.7)$ \\
Breakthrough & 0 & $5(2.7)$ \\
Early stop; AE & $8(17.8)$ & $28(15)$ \\
Sustained virological response by hepatitis C virus genotype & \\
1 & $13(48.1)$ & $40(38.1)$ \\
2 or 3 & $13(72.2)$ & $52(65.8)$ \\
4 & 0 & $1(33.3)$ \\
\hline Data are presented as $n$ (\%). AE adverse effect of antiviral therapy
\end{tabular}

Data are presented as $n$ (\%). AE adverse effect of antiviral therapy

shortage of family physicians in Canada is increasing for a variety of reasons such as requirements for longer physician training, restrictions on foreign-trained physicians and an increase in the average age and number of physicians retiring (8). Approximately $56 \%$ of prevalent HCV cases and almost all new infections acquired in Canada are related to injection drug use, with an estimated 20\% occurring among the immigrant community; both groups whose access to primary care may be even less optimal (9) than that of the general population. Providing an option to access hepatitis $\mathrm{C}$ care through self-referral - as supported by our data - should increase the ability to provide hepatitis care to the rising number of Canadians without a primary care physician.

Potential drawbacks to allowing self-referral for HCV care may include more 'inappropriate' referrals, such as those who are HCV RNA-negative or have absolute contraindications to therapy. This scenario has not been observed in our experience. Patients who self-referred were similar to those who were physician-referred in all baseline characteristics, including the proportion who were HCV RNA-negative, and were equally as likely to be treated and achieve an SVR.

Our data emphasize the need for additional education for primary health care providers and the general public. This is underscored by the fact that $16 \%$ of $\mathrm{HCP}$-referred patients were HCV RNA-negative and that a commonly cited reason for self-referral was being told by a primary care provider that their infection was 'dormant' or that there was no treatment available. Similar findings were described in a recent survey (10) of members of the New Jersey Academy of Family Physicians, which highlights the insufficient knowledge of family physicians about screening and counselling for chronic hepatitis.

In both HCP- and self-referred groups, approximately onethird of patients were started on HCV therapy, comparable with other large clinical series (11). Also comparable with other clinic experiences (12) and between the two groups was the SVR in our population: $38 \%$ to $48 \%$ of HCV genotype 1 and $66 \%$ to $72 \%$ of genotype 2 or 3 fully evaluable patients achieved an SVR. Importantly, the ability to self-refer also 
provided access to risk reduction education, screening for HIV coinfection and appropriate vaccination against hepatitis $\mathrm{A}$ and $B$.

Given that the prevalence of hepatitis $\mathrm{C}$ in Canada is increasing, improving access to hepatitis $\mathrm{C}$ care and treatment is a vital component in the strategy to limit the impact of hepatitis $\mathrm{C}$ infection on the Canadian health care system. Our data suggest that given the opportunity, patients infected with hepatitis $C$ will access care through a self-referral process, thereby resulting in an appropriate provision of care to a group who may otherwise not have had access.

\section{REFERENCES}

1. Zou S, Tepper M, Giulivi A. Current status of hepatitis C in Canada. Can J Public Health 2000;91(Suppl 1):S10-15,S10-6.

2. Remis R. Understanding the epidemiology of hepatitis $\mathrm{C}$ infection in Canada. The Canadian Consensus Conference on the Management of Viral Hepatitis. Toronto, Ontario, January 4 to 5, 2007.

3. Intraobserver and interobserver variations in liver biopsy interpretation in patients with chronic hepatitis C. The French METAVIR Cooperative Study Group. Hepatology 1994;20:15-20.

4. Fried MW, Shiffman ML, Reddy KR, et al. Peginterferon alfa-2a plus ribavirin for chronic hepatitis $\mathrm{C}$ virus infection. $\mathrm{N}$ Engl J Med 2002;347:975-82.
5. Hadziyannis SJ, Sette H Jr, Morgan TR, et al. Peginterferon-alpha2a and ribavirin combination therapy in chronic hepatitis $\mathrm{C}$ : A randomized study of treatment duration and ribavirin dose. Ann Intern Med 2004;140:346-55.

6. Manns MP, McHutchison JG, Gordon SC, et al. Peginterferon alfa- $2 \mathrm{~b}$ plus ribavirin compared with interferon alfa- $2 \mathrm{~b}$ plus ribavirin for initial treatment of chronic hepatitis C: A randomised trial. Lancet 2001;358:958-65.

7. Heslin KC, Andersen RM, Ettner SL, et al. Do specialist selfreferral insurance policies improve access to HIV-experienced physicians as a regular source of care? Med Care Res Rev 2005;62:583-600.

8. Kondro W. Where have Canada's general practitioners gone? Lancet 2002;359:2175.

9. Sherman M, Shafran S, Burak K, et al. Management of chronic hepatitis C: Consensus guidelines. Can J Gastroenterol 2007;21(Suppl C):25C-34C.

10. Ferrante JM, Winston DG, Chen PH, de la Torre AN. Family physicians' knowledge and screening of chronic hepatitis and liver cancer. Fam Med 2008;40:345-51.

11. Falck-Ytter Y, Kale H, Mullen KD, Sarbah SA, Sorescu L, McCullough AJ. Surprisingly small effect of antiviral treatment in patients with hepatitis C. Ann Intern Med 2002;136:288-92.

12. Jacobson IM, Brown RS Jr, Freilich B, et al. Peginterferon alfa-2b and weight-based or flat-dose ribavirin in chronic hepatitis $\mathrm{C}$ patients: A randomized trial. Hepatology 2007;46:971-81. 


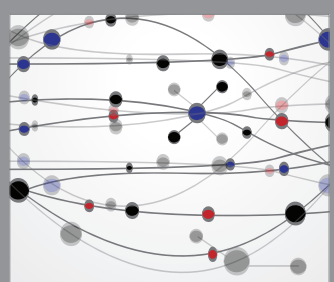

The Scientific World Journal
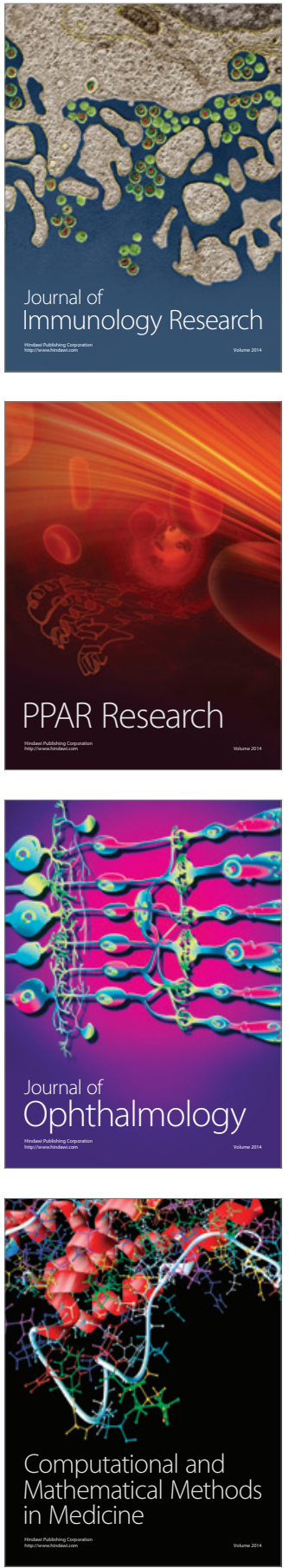

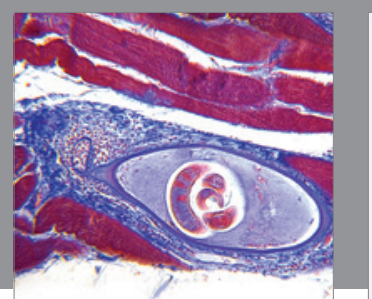

Gastroenterology Research and Practice

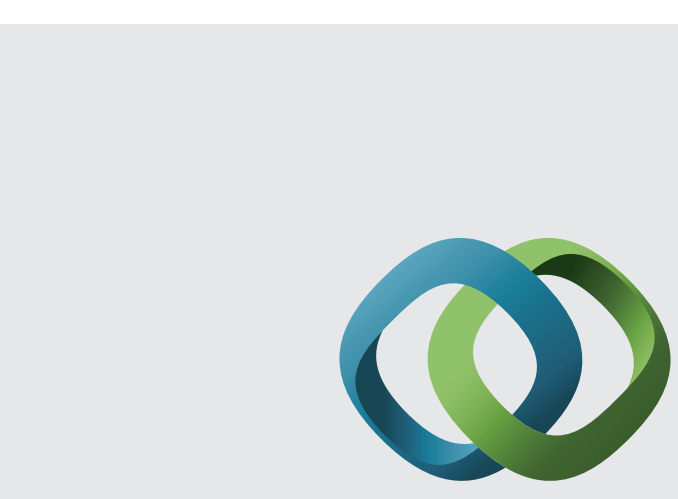

\section{Hindawi}

Submit your manuscripts at

http://www.hindawi.com
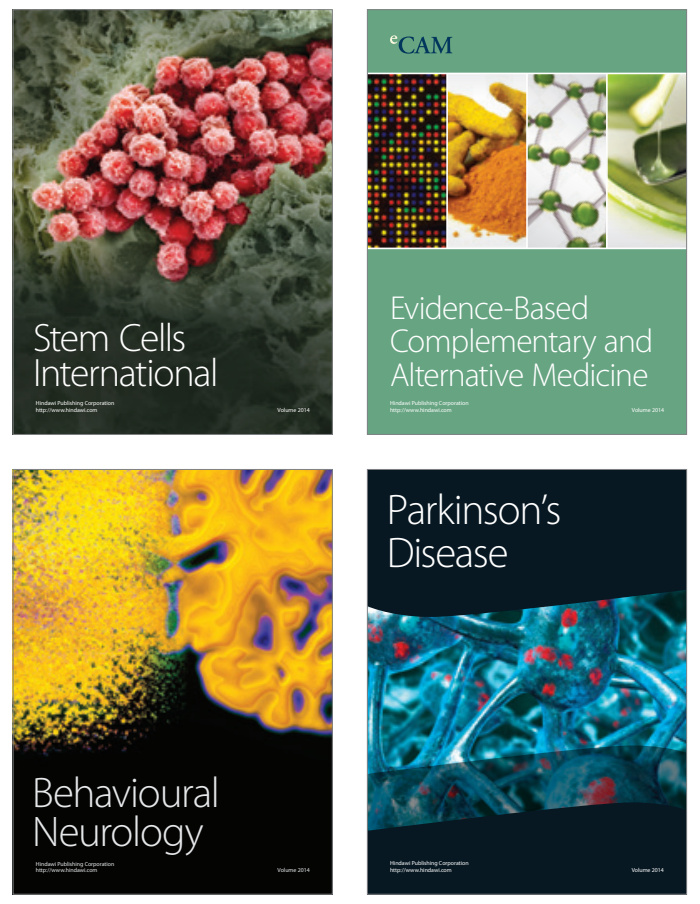
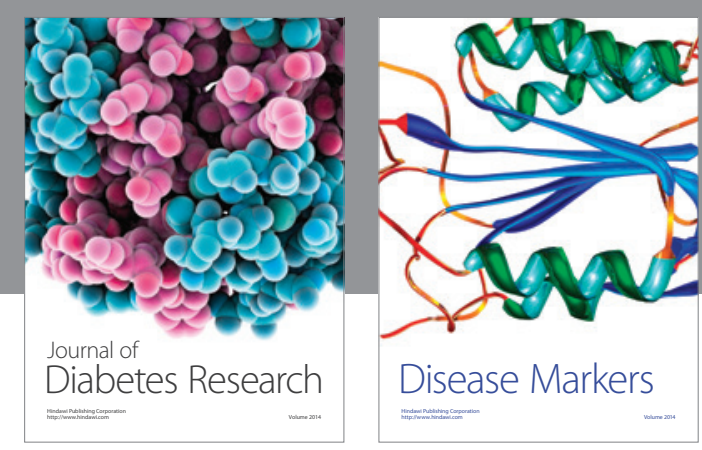

Disease Markers
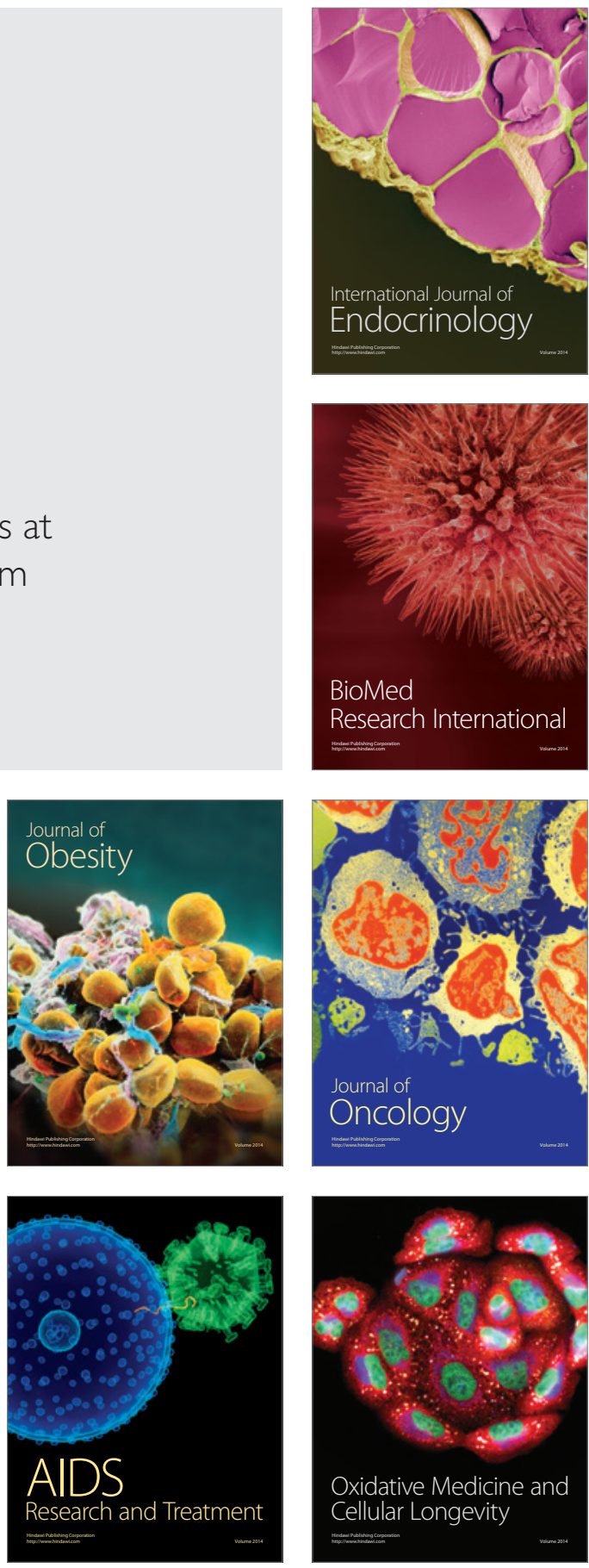